\title{
A PROPÓSITO DE UNA PUBLICACIÓN: \\ PICASSO, J. (TRADUCCIÓN, PRESENTACIÓN Y ANOTACIÓN), SAN AMBROSIO. LOS DEBERES. LOS HIMNOS, LIMA, FONDO EDITORIAL UCSS, 2009.*
}

En primer lugar, quisiera agradecer la invitación de los organizadores de este evento. Sabemos que no es común en Perú ver publicaciones como la que hoy nos congrega. Y no es común porque las editoriales locales, en su gran mayoría, no llegan a percibir el valor de obras como Los Deberes - o De Officiis- y los Himnos de san Ambrosio. Actualmente, el éxito editorial se suele medir a partir de resultados económicos, busca contentar la demanda, da mucha importancia a la moda, a la actualidad, a líneas particulares de pensamiento. Todo ello, la mayoría de las veces, excluye a priori publicaciones como la que hoy comentamos. Además, entiendo que los fondos editoriales universitarios dan prioridad, con justa razón, a las investigaciones de sus profesores. Pues bien, son raras, y a la vez gratas, las ocasiones en las que nos encontramos con una publicación de un estudioso peruano que desarrolla temas del cristianismo antiguo, de la patrística. Y aun más rara es la ocasión de encontrarnos con la traducción de una obra patrística. Ni qué decir, en el colmo de la rareza, encontrar que la primera traducción en español de una obra patrística se haya realizado en nuestro medio. El profesor Julio Picasso y el Fondo Editorial de la Universidad Católica Sedes Sapientiae nos ofrecen hoy esta rarísima, y — una vez más - grata, ocasión. Por todo ello, el estado de sorpresa y los gestos de felicitación son del todo justificados.

La publicación que me dispongo a comentar es fruto de un paciente y competente trabajo de traducción y anotación. Y digo esto porque me

* Comentario de Giancarlo Bellina, experto en patrística, ofrecido en la presentación pública de esta traducción de la obra ambrosiana (viernes 17 de julio de 2009) 
consta. Pero antes quisiera referirme a alguien que está detrás de ello, alguien que dedicó casi tres décadas de su vida a la investigación y a la edición crítica latina de Los Deberes de San Ambrosio. Me refiero al recientemente fallecido Padre Maurice Testard (1921-2006) (1). Después de haber publicado, en 1974, la edición crítica con traducción francesa del De officiis de Cicerón para Les Belles Lettres (2), Testard emprendió la tarea en vista de la publicación de la obra homónima ambrosiana. En efecto, diez años más tarde apareció la primera parte de su trabajo; en 1992 fue publicada la segunda y última parte (3). Testard intervino en congresos internacionales de ese entonces, comentando el De officiis de San Ambrosio bajo varios puntos de vistas (4). Con todo, Testard prosiguió sus investigaciones y, para el año 2000, tuvo lista una nueva edición crítica latina, la misma que ahora encontramos en el tomo XV de la Pars V de la Colección Corpus Christianorum Series Latina (5). En el Prefacio de esta publicación, Testard nos informa que hay diferencias importantes con respecto a su anterior edición francesa: algunos cambios en el texto latino (sobre todo en el comienzo del primer libro y en el final del tercero), revisión de las fuentes y de los datos filológicos, un nuevo aparato crítico, reorganización de la presentación de los manuscritos — sumando uno nuevo, recientemente re-descubierto-. En los agradecimientos, reconoce que Les Belles Lettres concedió los permisos necesarios para volver a utilizar el texto publicado en esa editorial (6).

La anterior no quiere ser una nota ociosa. Tuve la oportunidad de compartir con el profesor Julio Picasso algunos de los artículos del incansable Testard. Entiendo que los grandes conocimientos de este latinista francés, junto a otros estudios más, han preparado y acompañado esta primera traducción española del tratado ambrosiano en cuestión. No podía haber sido de otra manera.

Otro aspecto que demuestra la gran valía de esta publicación es el alto dominio del latín del traductor. Confieso mi admiración por sus anteriores traducciones. En ellas también demuestra un buen dominio del español. Justamente, el ideal que se persigue en el trabajo de traducción suele ser presentado en dos momentos: primero, lograr la comprensión plena 
del texto antiguo; segundo, expresar fielmente su contenido en la lengua receptora. Al respecto, muchas voces se pronuncian negando la posibilidad humana de alcanzar este ideal. Pues bien, según la experiencia, me parece que el profesor Julio Picasso, si es que tampoco alcanzará este ideal en su vida terrena, no está alejado del mismo. En efecto, esta primera traducción española de Los Deberes de san Ambrosio tiene la particularidad de haber sido realizada por un traductor adiestrado. Algunos estudios han identificado, en el obispo de Milán, un exponente especial de la «antigua prosa de arte cristiana latina»: «una prosa poética sensible a la fuerza evocadora de las imágenes y extendida entre los diferentes planos conceptuales, unificados por la magia de la palabra» (7). Invito a todos ustedes a comprobar la validez de estas expresiones en relación a la traducción del profesor Julio Picasso. Las imágenes ambrosianas no pierden su fuerza evocadora; los planos conceptuales son tomados muy en cuenta y respetados. Cada palabra cumple su función de signo eficaz, integrador y transmisor del pensamiento. En fin, esta traducción tiene un lenguaje y un estilo que llevan en sí un gran valor literario. Es un buen ejemplo de cómo deberían ser traducidas al español las obras del obispo de Milán. Hasta hay momentos en su lectura que uno se inclina a pensar si es que san Ambrosio escribió Los Deberes en español.

La introducción y las notas son ágiles, preparando y acompañando la lectura de la obra ambrosiana, respectivamente. Así, podemos decir que los particulares más resaltantes quedan evidenciados con suficiencia. Cada lector podrá comprobar todo ello por sí solo. Quisiera ahora, más bien, tratar algunos aspectos importantes del contexto histórico y eclesial de esta obra ambrosiana. Me parece que este tipo de información servirá para dar aun más vida a la lectura de la misma. San Ambrosio llega a la sede episcopal de Milán hacia el año 373, a sus 35 años de edad aproximadamente. Como nos cuenta su biógrafo, el diácono Paulino, fue prácticamente arrebatado de la administración pública, por aclamación popular (8). En efecto, tuvo que apresurar su formación exegética y teológica, lo cual significó, por un lado, aprender a utilizar sus conocimientos de filosofía y retórica en la predicación y defensa de la fe, y por otro lado, ponerse al día en teología y en exégesis 
cristiana. Sus lecturas de ese entonces parecen centradas en Filón, Orígenes y Plotino; más adelante están presentes también las obras de san Basilio, san Atanasio y Dídimo el Ciego. Pero hay que poner mucha atención al respecto porque, en este caso, apresurar no significó 'improvisar'. La solidez de su doctrina está reflejada en sus escritos, los cuales muestran además esa funcionalidad que caracteriza casi toda la literatura cristiana antigua. Logró un estilo exegético en el que la interpretación literal o histórica valía por su potencialidad espiritual, por ser un paso hacia el sentido cristológico o eclesial. No podemos negar que su exégesis es limitada en muchos aspectos; fue fruto de su tiempo y de los medios que disponía. Con todo, era una exégesis al servicio de la predicación, centrada en el Misterio Pascual; una exégesis que hacía que la Palabra de Dios llegara a ser alimento espiritual para todos (9).

Pues bien, según las investigaciones de Testard (10), San Ambrosio habría comenzado a escribir Los Deberes después de la primavera del 386, finalizando esta labor por los años 388-389. En ese entonces la situación en el Imperio Romano era especial, lo sabemos todos. Fuertes cambios sacudían el mundo, señalando que una era finalizada, mientras que otra comenzaba a surgir. Muchos acontecimientos sucedidos en los decenios cercanos al año 400 muestran que uno de los problemas centrales de ese entonces fue la distinción entre paganos y cristianos. La cristianización del Occidente antiguo fue, a comparación de la cristianización del Oriente, tardía y menos profunda. «Los cristianos occidentales no podían encontrar detrás de ellos un largo periodo de asimilación. Ellos estaban más aislados en medio de los otros intelectuales y no tenían confianza en la propia capacidad de absorber la cultura de sus contemporáneos sin ponerse a discutir, elemento este tan característico de la cristiandad latina» (11). En efecto, el proceso rápido y masificado de la cristianización de la sociedad romana estaba despojando a los cristianos de su identidad. Las preguntas constantes, a la que casi unánimemente los escritos cristianos de ese tiempo quieren responder, son las siguientes: ¿Qué significa ser un cristiano? ¿Cuáles son los confines del cristianismo y qué forma parte de su esencia? ¿En qué cree un cristiano? 
¿Cómo vive un cristiano? ¿Qué espera un cristiano? Las disputas doctrinales y disciplinales al interior de las comunidades cristianas muestran también esta labor de autodefinición. Surge así, sólo en época tardía, la distinción cristiana entre sagrado y profano, cuya línea de división servía para medir el grado de conversión al cristianismo.

Ese fue el tiempo de san Ambrosio. Los 24 años de su episcopado, llenos de actividad pastoral, son una respuesta a todas esas cuestiones antes mencionadas. Los Deberes no son la excepción. En efecto, esta obra literariamente lleva la forma de un tratado; con todo, hay razones suficientes para pensar que se trata más bien de un conjunto de homilías, organizadas y reelaboradas posteriormente en vista de su publicación. También está claro que San Ambrosio tomó como modelo literario el De Officiis de Cicerón (12): encontramos el mismo título, el mismo número de libros, los mismos puntos esenciales e imitación de algunos detalles. Pero el obispo de Milán logró una genial y radical cristianización del contenido. Según los estudiosos (13), la temática clásica estoica sobre lo útil y lo honesto era, de por sí, fácilmente transferible al ámbito cristiano. Pero no hay que subestimar el trabajo de San Ambrosio. Él comprendía demasiado bien la utilidad de la ética clásica para la formación de la conducta de vida. Pero también era consciente que su labor de predicador le exigía alimentar al pueblo con la Palabra. Así pues, realizó un trabajo de presentación de las virtudes escogiendo ejemplos bíblicos de conducta. En este sentido entiendo lo que el profesor Julio Picasso me decía en pleno trabajo de traducción: san Ambrosio, más que seguir a Cicerón, lo usa con mucha independencia. Pero hay un dato particular e importante que debemos subrayar. San Ambrosio, como cristiano, señala una finalidad del actuar del hombre distinta al simple ideal de la virtud estoica: la felicidad eterna en Dios. "A la luz de esta perspectiva también los deberes cotidianos asumen diversa fisionomía y consistencia» (14). El resultado fue la creación del primer manual sistemático de ética cristiana, lo que ha sido considerado «un evento que marcó la historia de la ética» (15). 
Además, Los Deberes de san Ambrosio muestran que las Sagradas Escrituras cumplen un rol de purificación en la lucha contra los vicios y de iluminación en el trabajo de adquirir virtudes. El obispo de Milán considera que la unión con el único Verbo en la oración mística es el fin de todo trabajo exegético.

En fin, san Ambrosio en Los Deberes nos enseña que el cristiano (laicos, vírgenes consagradas, monjes, clérigos) practica las virtudes de una manera diferente y con un fin diferente. Autores muy cristianos del siglo IV, como san Ambrosio, coinciden con la tradición platónica de su tiempo al afirmar que la moralidad ascética del desapego constituye un medio para ganar la libertad interior, el poder sobre el cuerpo y sobre los propios deseos. Pero afirmar esto y quedarse ahí es reducir considerablemente el mensaje de estos escritores. Los Padres Griegos y Latinos de los siglos IV y $\mathrm{V}$ van más allá de todo intelectualismo o voluntarismo. Ellos confiesan su fe y predican - porque la viven - la necesidad de la gracia divina en el camino de la conversión continua. En líneas generales, la filosofía griega y helenista estimuló el pensamiento cristiano de los primeros siglos; pero no olvidemos que también contribuyó a una toma de conciencia cada vez más clara del mensaje cristiano, al comprobarse que éste no podía ser reducido a las categorías del pensamiento griego.

Sobre los Himnos de san Ambrosio cabe decir lo siguiente. Esta producción abrió nuevos horizontes en la poesía cristiana latina. Son poesía artística, solo que con una fuerte funcionalidad. En efecto, la «noble simplicidad» formal que los caracteriza se debe a que eran cantos destinados para el culto (16). La himnodia cristiana latina tiene una estrecha conexión con la liturgia. $\mathrm{Al}$ respecto, es muy lúcida la definición del Himno Cristiano que ofrecía san Agustín a su pueblo: «¿Saben ustedes que es un himno? Es un canto con alabanza a Dios. Si alabas a Dios pero no cantas, no dices un himno; si cantas pero no alabas a Dios, no dices un himno; si alabas algo que no pertenece a la alabanza de Dios, aunque alabes cantando, no dices un himno. Un himno, por tanto, tiene tres cosas: el canto, la alabanza y la 
alabanza de Dios. En efecto, la alabanza de Dios mediante un cántico se llama himno» (17).

Fue san Ambrosio quien popularizó el uso de los Himnos en Occidente y los convirtió en un elemento fijo de la liturgia. Por ello es considerado el padre del canto con himnos latinos. Su estilo es inigualable: entusiasmo extraordinario, contenidos populares, imágenes que hablan al corazón, discretos elementos doctrinales, referencia al encuentro místico con Dios. Se trata, por tanto, de un enriquecimiento, que no buscaba desplazar los cantos directamente bíblicos, sino poner, al lado de ellos, otros cantos compuestos para momento de celebración específicos. El pueblo de Milán, según san Agustín (18), se entusiasmaba al entonarlos, hasta el punto de entusiasmar a los más fríos. Este es un dato interesante. Con toda razón se puede decir que San Agustín descubrió en Milán, no tanto un neoplatonismo que lo conquistó, sino sobre todo una porción de la Iglesia del Señor, la Iglesia que tenía como pastor a san Ambrosio y que vivía intensamente su fe, celebrándola, cantándola, perseverando. El pueblo vivía las luchas de su obispo; el obispo vivía para su pueblo. En este caso, el profesor Julio Picasso también ha sabido trasladar al español toda la riqueza expresiva de nueve Himnos ambrosianos, en su estilo y en su contenido.

Espero que esta publicación ocupe el lugar que se merece en todo Plan Lector. Las Casas de Formación, Seminarios y Bibliotecas de Teología tienen ahora como llenar un gran vacío. Auguro a todos una placentera y provechosa lectura. Gracias. 


\section{NOTAS}

1 Para más información: Deproost, P.-A., In memoriam R.P. Maurice Testard (1921-2006), en Revue des Études Augustiniennes et Patristiques, 52 (2006), pp. I-III. Para una lectura crítica de su aporte a los estudios ambrosianos, especialmente al De Officiis: Visonà, G., Lo 'Status quaestionis' della ricerca ambrosiana, en Pizzolato, L.F. y Rizzi, M., Nec timeo mori. Atti del Congresso internazionale distudi ambrosiani nel XVI centenario della morte di sant'Ambrogio, Milán, Vita en Pensiero 1998, pp. 45-50.

2 Testard, M. (edición, traducción y notas), Cicéron. Les Devoirs, Paris, Les Belles Lettres 1974.

3 Testard, M. (edición, traducción y notas), Saint Ambroise. Les Devoirs, Paris, Les Belles Lettres 1984-1992.

${ }^{4}$ Cf. La Bibliografía que ofrece la edición limeña en cuestión.

5 Testard, M. (edición y estudio), Sancti Ambrosii Mediolanensis De officiis [Corpus Christianorum. Series Latina: Tomus XV - Ambrosii Mediolanensis Opera: 5], Turnhout, Brepols 2000.

${ }^{6}$ Cf. Ibid., pp. V-VI.

7 Marin, M., La prosa d'arte cristiana latina, en Dal Covolo, E. y Sodi, M., Il Latino e i Cristiani. Un bilancio allinizio del terzo millennio, Ciudad del Vaticano, Libreria Editrice Vaticana 2002, pp. 32-33.

${ }^{8}$ Cf. Paulino, Vita Ambrosii 6-9. También, San Ambrosio, De Officiis, I,1,4.

9 Cf. De Margerie, B., Introduzione alla storia dell'esegesi. Vol. II: I primi grandi esegeti latini, Roma, Borla 1984, pp. 96-142. Cf. Pizzolato, L.F., La dottrina esegetica di Sant'Ambrogio, Milano, Vita e Pensiero 1978, pp. 305-326. 
Cf. Testard, M., Sancti Ambrosii... op. cit., pp. VII-VIII.

11 Markus, R.A., La fine della cristianità antica, Roma, Borla 1996, p. 49.

12 Cf. Simonetti, M. y Prinzivalli, E., Storia della letteratura cristiana antica, Asti, Piemme 1999, pp. 418-419. Ya con Minucio Félix, en el siglo II, comenzó la influencia de Cicerón en la literatura cristiana latina. Lactancio, siguiendo a Cicerón, había afirmado que la ética constituye el núcleo de la filosofía, por motivo de su utilidad como norma de vida (cf. Cicerón, De Officiis III,2,5; Lactancio, Divinae Institutiones III,7,1; VI,2,15). Cf. Hagendahl, H., Cristianesimo latino e cultura classica, Roma, Borla 1988, pp. 52-58 y 87-88.

${ }^{13}$ Cf. Simonetti, M. y Prizivalli, E., Storia... op. cit., p. 419. Testard, M., Sancti Ambrosii... op. cit., p. VII-XIII. Hagendahl, en cambio, entiende que San Ambrosio habría adoptado "con poquísimas variantes» la doctrina moral estoica a través de Cicerón: cf. Hagendahl, H., Cristianesimo... op. cit., p. 150.

${ }^{14}$ Cf. Simonetti, M. y Prinzivalli, E., Storia... op. cit., p. 419.

15 Cf. Hagendahl, H., Cristianesimo... op. cit., p. 150.

${ }^{16}$ Cf. Nazzaro, A.V., La poesia cristiana antica, en Dal Covolo, E. y Sodi, M., Il Latino e i Cristiani. Un bilancio all'inizio del terzo millennio, Ciudad del Vaticano, Libreria Editrice Vaticana 2002, pp.118-120. Cf. Simonetti, M. y Prizivalli, E., Storia... op. cit., pp. 421-423. Cf. Zelzer, K, Gli Inni di Sant'Ambrogio, en Salesianum 62, 2000, pp. 41-57.

17 San Agustín, Enarratio in Psalmo 148, 17.

${ }^{18}$ Cf. San Agustín, Confessiones IX, 7, 15. 